Graduate Institute of International and Development Studies

International Economics Department

Working Paper Series

Working Paper No. HEIDWP18-2019

\title{
Euro Area Sovereign Debt: Restructuring Options
}

\author{
Theresa Arnold \\ McGuire Woods LLP \\ Mitu Gulati \\ Duke University Law School \\ Ugo Panizza \\ Graduate Institute, Geneva \& CEPR
}

November 2019

Chemin Eugène-Rigot 2

P.O. Box 136

CH - 1211 Geneva 21

Switzerland

(C) The Authors. All rights reserved. Working Papers describe research in progress by the author(s) and are published to elicit comments and to further debate. No part of this paper may be reproduced without the permission of the authors. 


\title{
Euro Area Sovereign Debt: RESTRUCTURING OPTIONS
}

\author{
Theresa Arnold \\ Mitu Gulati \\ Ugo Panizza *
}

\begin{abstract}
Countries with large debts stocks are vulnerable to the vagaries of the markets. Confidence crises can arise out of nowhere, constricting access to the markets. Hence, the question arises as to whether these countries should put in place mechanisms that will help them better prepare for the possibility of crisis. In effect, the choice is whether to buy insurance. The cost of buying such insurance is that the possibility that markets will see the sovereign's proactive steps to protect against a crisis not as an indication of prudent governance but rather as an indicator that a crisis is imminent. In this article, we use the case of a hypothetical euro area country (Italy) with a large debt stock and a known vulnerability to confidence crises to set forth its options, as of 2019, to anticipate a possible future debt restructuring. It can: do nothing, do a little; and do something substantial.
\end{abstract}

Keywords: Sovereign debt, Italy, euro area, restructuring, local law advantage JEL Codes: F34,F54, G15, H12, H63, K22

\footnotetext{
* The authors are at McGuire Woods LLP, Duke University Law School, and The Graduate Institute Geneva (Department of Economics) \& CEPR, respectively. All views and errors are their own and not those of any institutions they are affiliated with. For conversations about the ideas in this paper, thanks to Lee Buchheit, Mark Weidemaier, Yannis Manuelidis, Jeromin Zettelmeyer and students in sovereign debt seminars in the Spring of 2019 at the European University Institute and Duke University Law School. The authors here are not experts in European law. They come at the problem addressed in this paper from the perspective of researchers on sovereign debt restructuring techniques.
} 


\section{Introduction}

How might a Euro area country that hits financial distress in 2020 do a debt restructuring? We assume, for purposes of analyzing this question, that almost all of the debt stock of this country will be governed by the sovereign's local law. The reason is that Euro area sovereigns have, since the $2011-13$ sovereign debt crisis, issued their sovereign debt almost exclusively in the form of local-law governed bonds. ${ }^{1}$

Having the bulk of its debt governed by its own laws gives the sovereign an advantagethe "local law advantage" 2 -in conducting a restructuring. This is the advantage that enabled Greece to restructure a major portion of its debt stock in March 2012, without facing holdout issues on the local-law debt. This was also the case with Barbados' debt restructuring in 2018, which followed the Greek template. However, both Greece and Barbados faced significant holdout problems in their foreign-law governed debt; many of the foreign-law creditors refused to take the same offers that were made to the local-law creditors and ended up receiving higher recoveries. ${ }^{3}$

In the analysis that follows, we focus on three strategies a Euro area sovereign might utilize in a possible future crisis to solve the primary source of disruption to modern-day sovereign debt restructurings: the holdout creditor problem. ${ }^{4}$ Therefore, in the analysis that follows, we assume that the sovereign and its official sector backers have been able to negotiate a restructuring deal with the majority of creditors, but those creditors do not want to enter into an agreement where either their recoveries are at risk of disruption from

\footnotetext{
${ }^{1}$ The two exceptions, Greece and Cyprus, were the worst hit in the crisis and have had to issue their post-crisis bonds under English law.

2 See Yannis Manuelidis, Using the Local Law Advantage in Today's Eurozone (With Some References to the Republic of Arcadia and the Mamatas Decision), 14 CAP. MKTS. L. J. 469 (2019); Lee C. Buchheit \& Mitu Gulati, The Local Law Advantage in Euro Area Sovereign Debt, 3 U. BolognA L. REV. 171 (2018); Lee Buchheit, Guillaume Chabert, Chanda De Long \& Jeromin Zettelmeyer, How to Restructure Sovereign Debt: Lessons From Four Decades, in SovEREIGN Debt: A Guide for Economists and Practitioners (S. Ali Abbas, Alex Pienkowski \& Kenneth A. Rogoff eds. 2019). ${ }^{3}$ As of this writing in October 2019, Barbados, having accomplished a Greek-style restructuring of its local-law governed debt by retrofitting the debt with collective action clauses, is still in negotiations with a subset of its foreign-law bondholders. See Daniel Bases, Barbados Reaches Debt Restructuring Deal With Creditors, LATIN FINANCE, October 21, 2019. On the Greek restructuring and the differential treatment of local and foreign-law bonds, see Jeromin Zettelmeyer, Christoph Trebesch \& Mitu Gulati, Greek Debt Restructuring: An Autopsy, 28 EcoN. PoLICY 513 (2013).

${ }^{4}$ See Buchheit et al., supra note 2 at Section VIII.
} 
litigation by holdout creditors or they are in danger of being embarrassed by having suffered much bigger haircuts than the holdouts.

We also put to the side the possibility of legal changes at the broader European level that might ameliorate the holdout problem more directly, ${ }^{5}$ and abstract from the possibility of reforms that will create a clear seniority structure within Euro area bonds. ${ }^{6}$

Although the analysis that follows might be applied to other Euro area sovereigns, we look specifically at Italy for purposes of our analysis. By using Italy as an example, we do not mean to suggest that it needs to restructure its debt preemptively. ${ }^{7}$ However, Italy did face a confidence crisis in late 2011.8 While financial conditions in the whole Euro area are now favorable and another crisis is unlikely, a gargantuan debt stock of around $€ 2.4$ trillion and a debt to GDP ratio of $135 \%$ make Italy vulnerable to another confidence crisis. ${ }^{9}$ Quite possibly, such a crisis could be dealt with through some combination of fiscal adjustment, economic reform, and official (ESM/OMT) financial support. This said, it is also conceivable that such a crisis might lead to a situation in which Italy might have to restructure its debts. We thus ask two related questions: in such a situation, what

\footnotetext{
${ }^{5}$ Legislation to protect the assets of a distressed sovereign from holdout creditors was used to considerable effect in Iraq's debt restructuring in 2005 and is currently in use in the context of Venezuela. See Lee C. Buchheit \& Mitu Gulati, Sovereign Debt Restructuring and US Executive Power, 14 CAP. MKTS. L. J. 114 (2019). For a discussion of how this strategy might be implemented in the Euro area context, see Lee C. Buchheit \& Mitu Gulati, Sovereign Debt Restructuring in Europe, 9 Global Policy 65 (2018); Lee C. Buchheit, Mitu Gulati \& Ignacio Tirado, The Problem of Holdout Creditors in Eurozone Debt Restructurings, ButTERWORTHS J. INT'L BANKING \& FINANCIAL L. 191 (April 2013).

${ }^{6}$ Proposals in this direction include the ideas of purple bonds and GDP indexed debt. See Lorenzo Bini Smaghi \& Michala Marcussen, Strengthening the Euro Area Architecture: A Proposal for Purple Bonds, SUERF Policy Note, Issue No 35)(2018); Guido Tabellini, Reforming the Eurozone: Structuring versus Restructuring Sovereign Debts, VoxEU (2017); Olivier Blanchard, Paolo Mauro \& J. Acalin, The Case for Growth-Indexed Bonds in Advanced Economies Today, Peterson Institute for International Economics, (Feb 2016). An alternative proposal which is fiscally neutral but could reduce the likelihood of rollover risk is the PADRE plan. See Pierre Pâris and Charles Wyplosz PADRE: Politically Acceptable Debt Restructuring in the Eurozone, Geneva Special Report on the World Economy 3, ICMB and CEPR (2014).

${ }^{7}$ For a discussion of the risks associated with a prepemtive Italian debt restructuring see Giampaolo Galli, Why Restructuring of the Italian Public Debt Should be Avoided (2018) (Osservatorio CPI https://osservatoriocpi.unicatt.it/cpi-Why a restructuring should be avoidced GG OCPI.pdf.); Ugo Panizza, Come Risolvere il Problema del Debito Pubblico Italiano: Un'analisi Critica Delle Soluzioni Facili, RIVISTA DI POLITICA ECONOMICA (forthcoming 2019).

${ }^{8}$ For a prior discussion by one of us, see Ugo Paniza, Public Debt in Italy: Myths, Facts and Policies (2014 draft), at http://repec.graduateinstitute.ch/pdfs/Working_papers/HEIDWP13-2014.pdf

${ }^{9}$ Ferdinando Giugliano, The Euro's \$2.7 Trillion Dollar Problem, Bloomberg, April 4 (2019), at https://www.bloomberg.com/news/articles/2019-04-04/the-euro-s-2-7-trillion-italy-problem ; Peter S. Goodman, Italy's Biggest Economic Problem? It's Still Italy, N.Y. TImES, Aug. 9 (2019), at https://www.nytimes.com/2019/08/09/business/italy-economy-debt.html
} 
restructuring options might Italy have? And could Italy do something now to put itself in a better position to deal with such a situation in the future?

Two considerations for any government in doing a debt restructuring are: (a) How to minimize the impact of that restructuring on its costs of future borrowing in situations where the sovereign needs to be able to tap those markets regularly; and (b) How to minimize the domestic economic and political costs in situations where a large portion of the debt is held domestically. The balance of the foregoing considerations, along with the interests of official sector sponsors, will determine how the choice among restructuring options is made. In this paper, we do not attempt the exercise of prescribing a specific restructuring plan for Italy. Instead, we put what we see as the most plausible options on the table.

The options to prepare for a possible future debt restructuring fall into three categories do nothing; do a little; or do a lot. One can think of these options in terms of the choice of what type of crisis insurance to buy: none at all; cheap, partial-coverage insurance; or expensive, full-coverage insurance.

The paper proceeds as follows. Part II describes the basic data on Italian sovereign debt. Part III, works through the three strategies noted above. Part IV concludes.

\section{Italian Sovereign Debt: 2019}

According to Italian Treasury and Bank of Italy data, at the time of writing total Italian public debt amounts to approximately $€ 2.4$ trillion (Table 1 ). ${ }^{10}$ The main holders of Italian public debt are domestic banks and other domestic financial institutions (€1.15 trillion, corresponding to $46 \%$ of the total), non-resident entities ( $€ 750$ billion, corresponding to

\footnotetext{
10 The most recent Bank of Italy data are available at https://www.bancaditalia.it/pubblicazioni/finanzapubblica/index.html. Treasury data on the composition of bonded debt are available at: http://www.dt.tesoro.it/en/debito pubblico/dati statistici/scadenze titoli suddivise anno/ . Bank of Italy data used in this paper refer to end of July 2019, while Italian Treasury data refer to end of September 2019. There is a small discrepancy between Bank of Italy data, which report a total for bonded debt of $€ 2,047$ billion, and Treasury data which report a total for bonded debt of $€ 2,020$ billion.
} 
$30 \%$ of the total), and the Bank of Italy (€406 billion, corresponding to $16 \%$ of the total). Italian households, who in the early 1990 s held about $50 \%$ of the Italian public debt, now hold less than $7 \%$ of the total.

About $83 \%$ of the total stock of Italian debt (€2 trillion) consists of tradable instruments (government bonds and bills). Most of the non-bonded debt is held by Italian banks ( $€ 270$ billion, corresponding to $65 \%$ of the non-bonded debt), resident households (€81 billion, corresponding to $20 \%$ of the non-bonded debt), and non-residents ( $€ 50$ billion, corresponding to $12 \%$ of the non-bonded debt). ${ }^{11}$

The data show that $43 \%$ of bonded debt is held by domestic banks and other domestic financial institutions, $34 \%$ by non-residents, $20 \%$ by the Bank of Italy, and the remaining $4 \%$ by households.

More than $99 \%$ of Italian bonded debt is denominated in euros (issues in US dollars amount to $€ 4.9$ billion, issues in British pounds amount to $€ 2.5$ billion, and issues in Japanese yen amount to $€ 200$ million; see Table 2). Most bonded debt consists of Treasury Bonds (BTP, $82 \%$ of the total), Treasury Certificates (CCT, $7 \%$ of the total), and Treasury Bills (BOT, $6 \%$ of the total), all of which are governed by local Italian law. ${ }^{12} \mathrm{~A}$ small share of bonds are listed on the Luxembourg exchange, under a Medium Term Note Program (EMTN). Most of these bonds are denominated in euros, but a small amount are in British pounds and Japanese yen. All of these Luxembourg-listed bonds, as best we can tell, are governed by local Italian law, although as we detail later, these bonds do have different (and better) legal protections for creditors than the aforementioned Treasury Bonds, Treasury Certificates and Treasury Bills. Finally there is a small amount of debt in the form of Global Bonds, issued under a US program and

\footnotetext{
${ }^{11}$ About half ( $€ 128$ billion) of the non-bonded debt held by Italian banks consist of direct loans. Post office savings certificates amount to $€ 69$ billion, explaining most of the difference between bonded and non-bonded debt held by households.

12 Treasury bonds have a maturity that ranges between 3 and 50 years. While most Treasury bonds are nominal, there are Treasury bonds indexed to Italian inflation (BTP Italia, about $4 \%$ of the total) and euro area inflation (BPT€i, about $9 \%$ of the total). CCTs have a maturity of 7 years and are indexed to short-term interest rates. BOT are zero-coupon bonds with maturities that range between 6 and 12 months.
} 
governed by New York law (roughly $€ 5$ billion, denominated in US dollars). ${ }^{13}$ In sum, about $99 \%$ of Italian debt is governed by local law and, therefore, benefits from the locallaw advantage (99.66\% if we include EMTN and $98.25 \%$ excluding EMTN; Figure 1$)$.

Table 1: Italian Public Debt, Composition by Holders (millions euro)

\begin{tabular}{llllll}
\hline Holder & $\begin{array}{l}\text { Total } \\
\text { Debt }\end{array}$ & $\begin{array}{l}\% \text { of } \\
\text { total }\end{array}$ & $\begin{array}{l}\text { Bonds } \\
\text { and bills }\end{array}$ & $\begin{array}{l}\% \text { of } \\
\text { bonds } \\
\text { and bills }\end{array}$ & $\begin{array}{l}\% \text { of } \\
\text { total debt }\end{array}$ \\
\hline $\begin{array}{l}\text { Bank of Italy } \\
\begin{array}{l}\text { Domestic Banks } \\
\text { Other Domestic }\end{array}\end{array}$ & $\begin{array}{l}406,482 \\
674,727\end{array}$ & $\begin{array}{l}16 \% \\
27 \%\end{array}$ & 402,152 & $20 \%$ & $99 \%$ \\
$\begin{array}{l}\text { Financial Institution } \\
\text { Other residents }\end{array}$ & 475,394 & $19 \%$ & 465,628 & $20 \%$ & $60 \%$ \\
Non-residents & 161,658 & $7 \%$ & 80,720 & $4 \%$ & $98 \%$ \\
\hline Total & 747,300 & $30 \%$ & 696,837 & $34 \%$ & $93 \%$ \\
\hline
\end{tabular}

Source: Own elaborations based on Bank of Italy data ending in July 2019

Table 2: Italian Government Bonds and Bills, Composition by Instrument (millions euro)

\begin{tabular}{|c|c|c|c|c|c|c|c|}
\hline Instrument & Euro & USD & GBP & JPY & Total & $\begin{array}{l}\% \\
\text { of total }\end{array}$ & $\begin{array}{l}\text { Without } \\
\text { CACs }\end{array}$ \\
\hline $\begin{array}{l}\text { BOT } \\
\text { BTP issued }\end{array}$ & 119,333 & & & & 119,333 & $5.9 \%$ & 119,333 \\
\hline $\begin{array}{l}\text { after } 2012 \\
\text { BTP issued }\end{array}$ & $1,061,022$ & & & & $1,061,022$ & $52.7 \%$ & \\
\hline before 2013 & 596,694 & & & & 596,694 & $29.5 \%$ & 596,694 \\
\hline CCTeu & 139,484 & & & & 139,484 & $6.9 \%$ & \\
\hline CTZ & 61,213 & & & & 61,213 & $3.0 \%$ & \\
\hline EMTN & 26,031 & & 2,516 & 200 & 28747 & $1.4 \%$ & 19,178 \\
\hline EUROBOND & 1,783 & & & & 1,783 & $0.1 \%$ & 1,783 \\
\hline GLOBAL & & 4,902 & & & 4,902 & $0.2 \%$ & 4,902 \\
\hline ISPA & 7,700 & & & & 7,700 & $0.4 \%$ & 7,700 \\
\hline Total & $2,013,260$ & 4,902 & 2,516 & 200 & $2,020,878$ & $100 \%$ & 749,590 \\
\hline
\end{tabular}

Source: Own elaborations based on Italian Treasury data ending in September 2019

13 This amount does not factor in the three new US dollar bonds issued on October 10 (2019) for a total of $\$ 7$ billion. The bonds had maturities of 5 years ( $\$ 2.5$ billion), 30 years ( $\$ 2.5$ billion) and 10 years ( $\$ 5$ billion). This was the first dollar issuance in nearly 10 years (the last was in September 2010), the ten-year bond was issued with 150 basis point spread over US Treasuries. These dollar bonds are not in our data which end on Septembner 30, 2019. 
About one-third ( $€ 597$ billion) of outstanding BTP were issued before 2013 and, hence, do not include collective action clauses ("CACs") that are now required by the EU in order to provide an orderly path to restructuring. ${ }^{14}$ Other bonds that do not include CACs include foreign-law bonds issued before 2004, ISPA bonds (these were bonds issued before 2013 to finance infrastructure projects), and BOT. In total, bonds and bills without CACs amount to approximately $€ 749$ billion (i.e., $37 \%$ of total outstanding bonded debt; $33 \%$ of the total if we exclude BOT, which amount to approximately $€ 120$ billion).

\section{Figure 1: The local law advantage in Italian bond-debt}

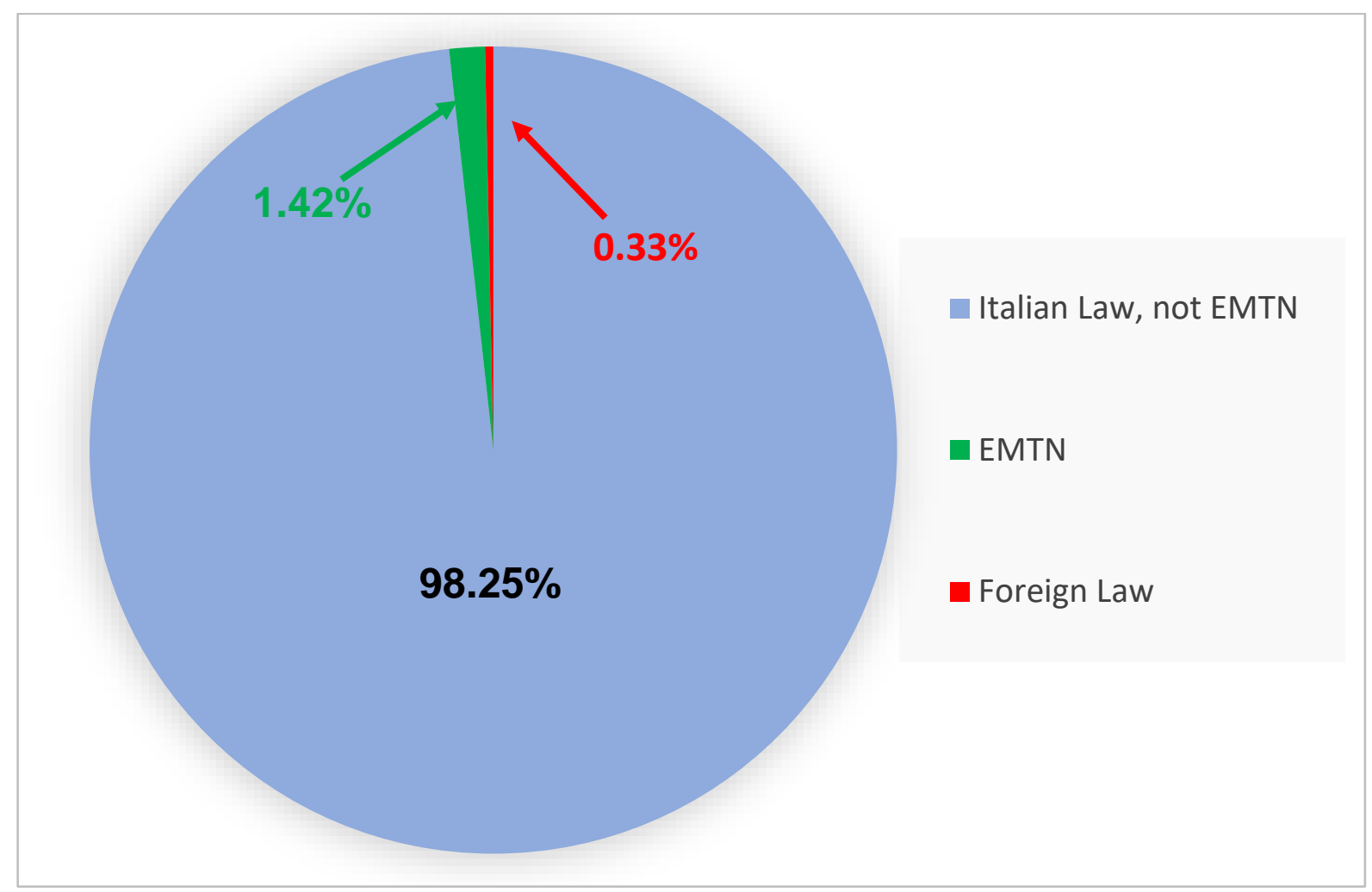

Source: Own elaborations based on Italian Treasury data ending in September 2019.

\footnotetext{
${ }^{14}$ While we use 2013 as cut-off point, during 2013 the Italian Treasury still issued some bonds with CACs. The 2013 Treasury report of Guidelines for Public Debt Management (available at http://www.dt.tesoro.it/en/debito pubblico/presentazioni studi relazioni/dettaglio.html?resourceType=/modules/debit o pubblico/presentazioni studi relazioni/elem 0007.html) states that: "Following the entry into force of the Treaty that determined the European Stability Mechanism, which foresaw the inclusion of CACs for all new Government bonds of the euro zone with maturities in excess of one year, the Treasury will albeit continue to issue, with its usual regularity, bonds without the above clauses, these being outstanding bonds at 01/01/2013 and off-the-run bonds, so as to guarantee the necessary liquidity." Hence, the share of bonds without CACs is likely to be slightly higher than what reported here.
} 
Figure 2 shows the maturity profile of outstanding Italian bonds. During 2020-21, the Italian Treasury will need to roll over about $€ 60$ billion per quarter, with large amounts of BTP without CACs that need to be rolled over in Q1 2020 and Q3 2021. ${ }^{15}$ Figure 3 shows the residual stock of bonds without CACs. While the curve is steep, starting with $€ 750$ billion in Q3 2019 and dropping to with $€ 500$ billion in Q4 2020, this is mostly due to maturing BOT. After the BOT effect ends, the curve flattens and by 2026, Italy will still have more than $€ 300$ billion of bonds without CACs. ${ }^{16}$

Figure 2: Bond maturing in each quarter by bond type (2019-2030) (millions euros)

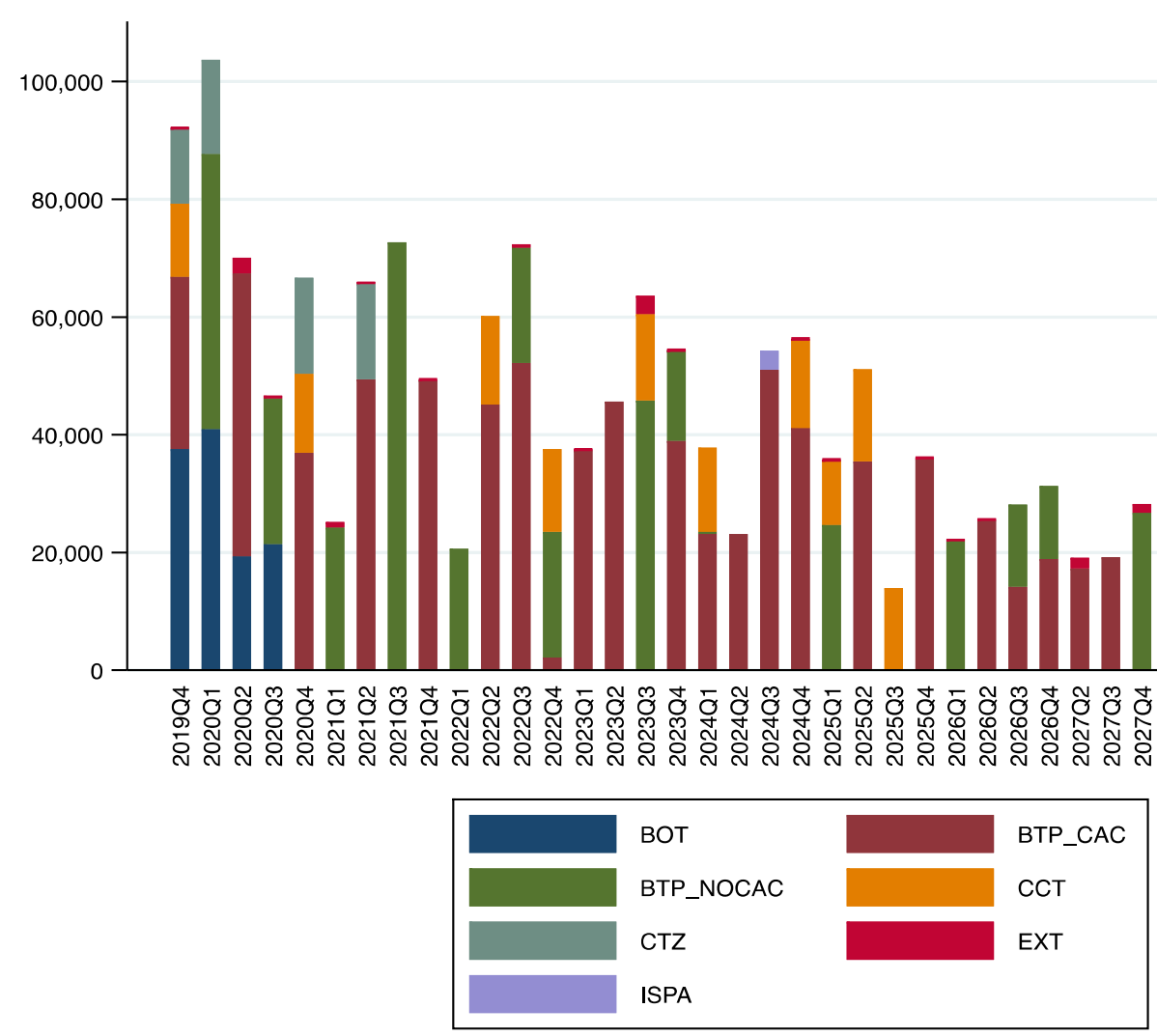

Source: Own elaborations based on Italian Treasury data ending in September 2019.

The graph is based on bonds issued before October 1, 2019. No assumption is made about the rollover of existing bonds. The category EXT includes EMTN, Global Bonds, and Eurobonds. BTP_NOCAC are BTPs issued before 2013 and BTP_CAC are BTP issued after 2012.

15 Note that we do not make assumptions about the rollover of existing debt. If the share of Treasury Bills remains constant, one should add about $€ 40$ billion of BOT that needs to be rolled over after Q3 2020.

16 These estimates are conservative because, as explained above, some of the bonds issued in 2013 don't have CACs, and the BOTs (which don't have CACs) will need to be rolled over (see Figure 4 for assumptions on BOTs rollover). 
Figure 3: Residual stock of bonds without collective action clauses (2019-2040) (millions euros)

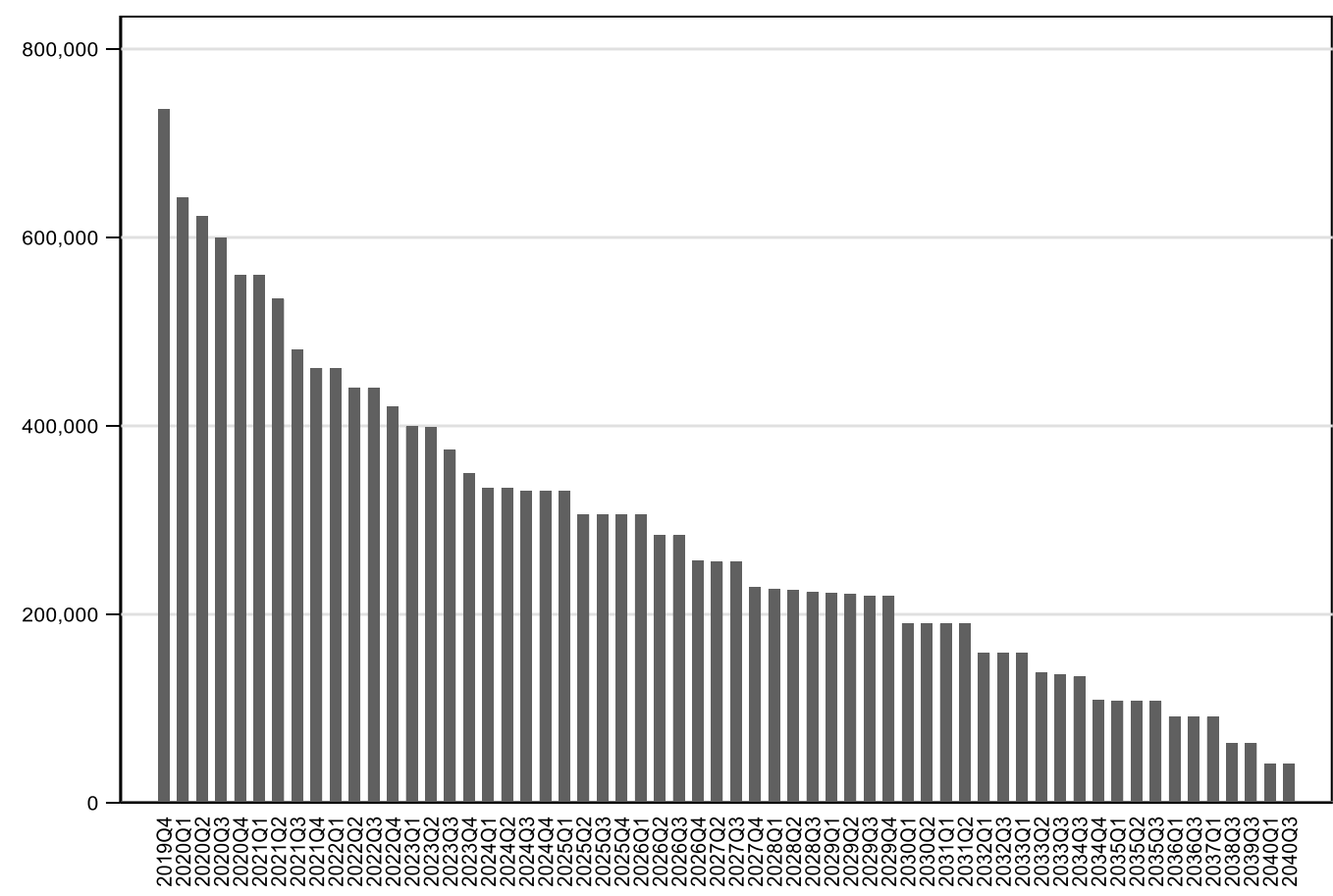

Source: Own elaborations based on Italian Treasury data ending in September 2019.

The graph is based on bonds issued before October 1, 2019. No assumption is made about the rollover of existing bonds. The graph is built under the assumption that bonds issued before 2013 don't have CACs and that external bonds don't have CACs, with the exception of EMTN issued after 2012 (the outstanding stock of EMTN with CAC is $€ 6.8$ billion).

The top panel of Figure 4 plots the expected composition of Italian bonded debt over the period $2019-2023$. It shows that in 2023 , more than $15 \%$ of bonded debt will still consist of long-term bonds without CAC, if we add BOTs and hard-to-restructure foreign-law and EMTN bonds, we find that in 2023, almost one-quarter of Italian debt will take the form of hard-to-restructure debt. If to this debt we add loans (ie non-bond debt), we find that only two-thirds of Italian public debt consists of bonded debt with CACs (bottom panel of Figure 4) 
Figure 4: Expected Composition of Italian Debt (2019-2023)

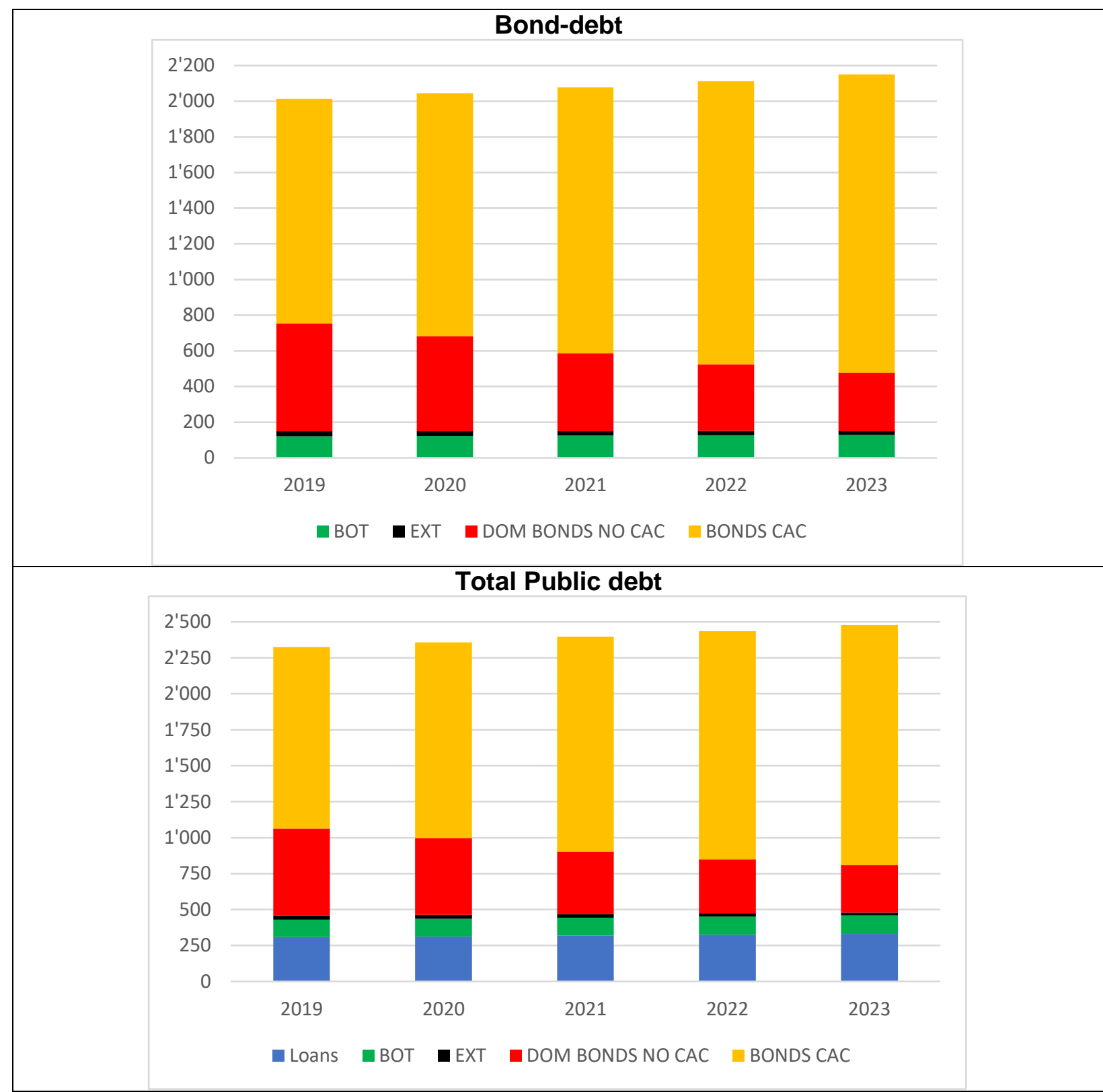

Source: Own elaboration based on IMF data and Italian Treasury data. In order to build the debt composition for 2020-2023, we started with IMF forecasts for the total stock of debt and then assumed that the shares of loans and BOT remain constant. Data for external debt, and domestic bonds are instead taken from the flow of maturing bonds data used for Figure 2. The graph is built under the conservative assumption that no external bonds will be issued in the next three years; while Italy issued dollar bonds in October 2019, this was a small amount ( $\$ 7$ billion) and this issuances -and possible future external issuances- are unlikely to substantially change the figure given their relatively small amount. 


\section{The Options Now}

A.

Do Nothing

The do nothing approach is for the Italian authorities to literally do nothing. That is, to take no steps to utilize the local-law advantage in advance of a potential crisis. This is perhaps the most likely outcome, since governments are loath to admit that a debt crisis might be in the offing. The main reason for the do nothing approach is the concern that taking steps to prepare for a crisis will send a negative signal to the market and either lead to an increase in sovereign yields or, worse, cause the crisis to happen. ${ }^{17}$

In most cases, this head-in-the-sand approach is far from ideal. But, as explained below, it may not be a terrible approach in the Italian case, given the advantages the legal terms governing the current Italian debt stock provide.

As a starting point, Italy will have first-generation Euro CACs in over $75 \%$ of its bonded debt stock by mid 2020 (60\% of its total debt stock, see Figure 4 ). These clauses were put in place starting in January 2013, mandatorily, for all Euro area sovereign debt issuances of over a year in maturity.

Simplifying somewhat, the presence of these clauses means that all of the bonds containing them can be modified in a single transaction, so long as the approval of $66.67 \%$

\footnotetext{
${ }^{17}$ For the argument that whatever may make a debt restructuring process smoother is optimal ex-post but not ex ante, see Michael P. Dooley, International Financial Architecture And Strategic Default: Can Financial Crises Be Less Painful?, 53 Carnegic-Rochester Conference Series on Public Policy 361 (2000); Andrei Shleifer, Will the Sovereign Debt Market Survive?, 93 AMER. ECON. REV. 85 (2003). The same argument has come up on multiple occasions in the context of the introduction of collective action clauses across a variety of settings over the years. E.g., Anna Gelpern \& Mitu Gulati, Public Symbol in Private Contract, 84 WaSH U. L. Rev. 1627 (2007). And that includes, most recently, Italian resistance to a move to single-limb CACs for Euro area sovereign bonds. See e.g., Jan Strupczewski, EU Leaders to Boost Bailout Fund Role, But Duck Talks on Deposit Insurance, REUTERS, June 26 (2018) (noting the strong opposition of the Italian government to the use of single-shot CACs). However, two generations of empirical research on the price impact of the insertion of collective action clauses in sovereign bonds that, if anything, shows the opposite effect. E.g., Mattia Picarelli, Aitor Erce \& Xu Jiang, The Benefits of Reducing Holdout Risk: Evidence From the Euro CAC Experiment: 2013-18, 14 CAP. MKTS L. J. 155 (2019); Christoph Grosse Steffen, Julian Schumacher \& Sebastian Grund, Collective Action Clauses in the Euro Area: A Law and Economics Analysis of the First Five Years, 14 CAP. MkTs L. J. 134 (2019); Paolo Colla et al., The Price of Law: The Case of the Eurozone Collective Action Clauses (2018 draft), at https://papers.ssrn.com/sol3/papers.cfm?abstract id=2817041.
} 
of the holders of each bond and $75 \%$ of the holders in all the bonds put together (in principal amount) is obtained.

However, there are issues. The requirement that the approval of $66.67 \%$ of the creditors in each bond be obtained to effect a consensual debt restructuring gives rise to the risk of holdout creditors targeting a subset of the smaller bonds and accumulating blocking positions in them. In the Greek restructuring of 2012, where the majority of foreign-law bonds were governed by English law and had CACs that could only be activated with super-majority votes, there were holdouts in 25 separate sovereign and sovereign guaranteed bonds (amounting to about $€ 6.4$ billion in face amount of debt). The holdouts, after blocking the votes in their bonds, got paid in full. And this was in large part because Greece did not want to risk the type of litigation that Argentina was suffering at that same time. ${ }^{18}$

For the Italian local-law bonds with CACs, the vote requirement is lower than what was required in the Greek foreign-law bonds ( $75 \%$, with a quorum requirement in the context of a bondholder meeting). But this is unlikely to be a significant barrier for a well capitalized hedge fund seeking to utilize the holdout strategy.

In addition, if a creditor can figure out what the holdings of the ECB are in particular bonds (and they are substantial in many bonds), she will be in an even stronger position to hold out. The reason is that the ECB has asserted a commitment to not voting in favor of any debt restructuring plan. ${ }^{19}$ In a CAC that calls for an affirmative vote of the creditors of a certain percentage of principal amount, abstention is scored as a no vote. The ECB's commitment, therefore, effectively lowers the percentage the holdout would be required to purchase in order to block a modification. ${ }^{20}$

\footnotetext{
${ }^{18}$ For details, see Zettelmeyer et al., supra note 3.

19 See Francesco Canepa, Loophole May Clear ECB's Way to Buying More State Debt, REUTERS, June 26, 2019.

20 ld.
} 
The foregoing has already caused concern in policy circles-and has resulted in proposals for the Euro area to reform its CACs starting in 2020. ${ }^{21}$ That said, an argument could be made that the potential holdout problem is less serious than it has been made out to be. One way to see this is by detailing the steps a holdout creditor seeking to litigate against a distressed sovereign generally needs to take.

Assuming that the bond in question has not yet come due but the sovereign is in default on other indebtedness, the holdout will typically utilize her bond's cross default provision to accelerate the payments owed on her bond, demanding immediate payment of principal and accrued interest. The ability to declare a default and accelerate is key in the litigation context because suing the sovereign on small unpaid coupon payments is unlikely to be worthwhile when measured against legal costs.

Italian local-law bonds though, except for the sliver listed in Luxembourg under the EMTN program, have neither cross default nor acceleration provisions. In other words, the only bonds worth holding out on will be the ones where a substantial principal amount is due. Worse, from the holdout creditor's perspective, those bonds (except again for the Luxembourg-listed ones) lack explicit waivers of sovereign immunity from either suit or execution, which means that the Italian government lawyers can potentially use that as a defense. ${ }^{22}$ Put that together with the dysfunction of the Italian legal system, ${ }^{23}$ and it is hard to imagine one of the specialist hedge funds that won large recoveries against Argentina in the New York courts wanting to invest in holding out on the non-Luxembourg listed Italian local-law bonds

By contrast to Italian creditors, the foreign-law holdout creditors in the Greek restructuring in 2012 had the rights to declare cross defaults, accelerate the debt, and sue for recovery

\footnotetext{
21 See e.g., Christophe Destais, Frederik Eidam \& Friedrich Heinemann, The Design of a Sovereign Debt Restructuring Mechanism for the Euro Area: Choices and Trade Offs, CEPII Policy Brief No. 25 (March 2019); Jeromin Zettelmeyer, Managing Deep Debt Crises in the Euro Area: Towards a Feasible Regime, 9 GLOBAL Policy 70 (2018).

22 One key question will be whether there is an implicit waiver of sovereign immunity under Italian law.

23 In the most recent Doing Business ranking from the World Bank, Italy ranks $122^{\text {nd }}$ out of 190 countries in terms of ease of contract enforcement. Average enforcement time is 1,120 days and the cost of litigation, as a fraction of the claim, is $27.6 \%$. Those do not strike us as numbers that would attract litigation oriented holdout creditors. For details, see https://www.doingbusiness.org/content/dam/doingBusiness/country/i/italy/lTA.pdf
} 
in English, Swiss or Japanese courts under the explicit consents to jurisdiction and waivers of immunities from suit and execution in the contracts. Absent those rights to declare defaults, accelerate, bring suit and execute against the state's assets in a jurisdiction where the legal system moves quickly and efficiently, a sovereign such as Italy might hope that it would simply be unattractive for any investors in its bonds to hold out. If so, doing nothing might work.

That said, the costs of default for a country that needs to regularly tap the borrowing markets can be substantial. And potential holdout creditors, especially if they watched what happened in Greece a few years prior, might recognize their potential to impose costs on Italy even in the absence of substantial litigation rights. ${ }^{24}$ This is because during the restructuring period the country is likely to be given a Selective Default rating by the credit rating agencies, which will make new borrowing hard. ${ }^{25}$ Plus, its bonds likely won't be eligible for delivery at the central bank's discount window, making them an unattractive investment. The end result will probably be an increase in sovereign borrowing costs beyond the ususal default penalty. All in all, a country like Italy may not want to have a number of defaulted bonds outstanding after its restructuring.

\section{B. Do a Little}

Let us assume that the prospect of being in a long-term payment default vis-à-vis a substantial number of creditors, even if their litigation options are not attractive, is a prospect that the Italian government does not relish. Let us also assume that the government has taken no steps prior to the crisis to put in place mechanisms to reduce the likelihood of holdouts. The question then is whether there are some non obvious options available under existing Italian law.

\footnotetext{
24 This is what happened in 2012 with Greece's local-law governed guaranteed bonds where CACs were not legislatively imposed. Greece could have resisted paying the holders of these bonds who refused the restructuring until they accepted the offer. But it did not wish to be in continuing default and, therefore, paid them in full.

${ }^{25}$ See Ugo Panizza, Federicao Sturzenegger \& Jeromin Zettelmeyer, The Economics and Law of Sovereign Debt and Default, 47 J. Econ. Lit. 651 (2009).
} 
We see two: (a) An extension of maturities of those bonds that were issued at low rates in prior years and that are coming due; and (b) The imposition of a withholding tax equivalent to the haircut taken voluntarily by non holdouts. As we discuss further below, these options pose some litigation risk, and Italy might choose to "do a little" by taking steps to mitigate that risk.

As a threshold question to examining these options, we must ask whether Euro area countries contemplating a restructuring are constrained to utilizing only the current Euro CACs and no other technique. The answer here, we think, is no for a number of reasons, including the explicit language of the policy directive implementing these CACs to the policy intent behind them. ${ }^{26}$

To clarify the question, let us say that the Italian government decides that it wants to reduce its debt burden by imposing a withholding tax (more on this later). Do the Euro CACs in its existing bonds bar the use of this strategy?

No. There is nothing in the mandate requiring the inclusion of Euro CACs that constrains any individual Euro area country from using its tax authority. Indeed, there could not be, as Italy has retained the authority to levy taxes, even as it has delegated other aspects of sovereignty to the Euro area. Italy is constrained in terms of the contract provisions it has agreed to with bondholders, but the vast majority of its local-law bonds (except those pesky Luxembourg-listed ones) do not contain the protections against the sovereign imposing withholding taxes that are standard in foreign-law bond issuances (including in those issued by Italy).

A similar analysis applies to other routes to enabling a easier restructuring, such as making it harder to sue in Italian courts; increasing the costs of litigating a contracts case,

\footnotetext{
${ }^{26}$ We draw heavily from recent papers by sovereign debt experts Mark Weidemaier and Yannis Manuelidis on this point. See W. Mark C. Weidemaier, Restructuring Italian (or Other Euro Area) Debt: Do Euro CACs Constrain or Expand the Options (2019 draft), at https://www.ssrn.com/abstract=3364982 ; Manuelidis, supra note 2; see also Buchheit \& Gulati, supra note 2; Tyler Zellinger, A Long Road to Nowhere: The Legal and Remedial Futility of Challenges to a Restricted Single-Limb Retrofit of Local-Law Italian Debt Stock (2019 draft), at https://papers.ssrn.com/sol3/papers.cfm?abstract id=3371876
} 
for example. That would not be particularly good for the Italian legal system and economy generally, but it would deter holdout creditors with debt instruments whose holders were required to litigate in Italian courts under Italian law. And there is nothing in the body of European law respecting CACs that constrains Italy from taking such actions.

The language of the CACs themselves signals the possibility of other restructuring techniques being used. In relevant part, they say:

In the case of a cross-series modification, the terms and conditions of the Bonds and debt securities of any other series ... may be modified in relation to a reserved matter with the consent of the Issuer and [the requisite proportion of bondholders]. ${ }^{27}$

The word "may" is crucial; it tells us that the CACs are a debt restructuring option that the sovereign may use. But just one option. ${ }^{28}$ If these CACs were meant to say that sovereigns were constrained from using other restructuring options, they would have said "must" instead of "may".

One might ask whether there is anything in the ESM Treaty, whose Article 12 mandated that all Euro area nations utilize CACs, suggesting that future debt restructurings of the bonds with CACs could only proceed by utilizing the CACs. There is not. Nor is there anything in the history of why these CACs were put in place by the European authorities that suggests so. The history tells us that, starting with the infamous Deauville beach walk on October 19,2010, the utilization of CACs was meant to set up an orderly mechanisms for future debt restructurings in Europe and to signal to investors that the purchasers of Euro area sovereign bonds that those bonds could be restructured in the future. ${ }^{29}$

\footnotetext{
27 (emphasis ours). For a discussion, see Zellinger, supra note Error! Bookmark not defined. .

28 See Weidemaier, supra note Error! Bookmark not defined..

${ }^{29}$ One of us co authored a study reporting on interviews with Euro area policy makers, debt managers, and lawyers involved in the creation of the Euro CACs. See Anna Gelpern \& Mitu Gulati, The Wonder Clause, 41 J. CoMP. EcoN. 367 (2013); see also Antonio Sáinz de Vicuña y Barroso, Identical Collective Action Clauses for Different Legal Systems: A European Model at 20, in Collective Action Clauses AND the Restructuring of Sovereign Debt (Patrick Kenadjian, Klaus-Albert Bauer \& Andreas Cahn eds. 2013). More generally, see the papers in COLLECTIVE ACTION Clauses and the Restructuring of Sovereign Debt, id.
} 
Mark Weidemaier, in his 2019 paper, sums this up:

[A Euro area] sovereign that has issued local-law debt [with CACs] remains free to alter its law to facilitate restructuring, although it will encounter various legal constraints in doing so. These constraints, however, are not absolute; there is room for the prudent exercise of local law advantage.

Having determined that the existence of the CACs does not preclude the sovereign from using the local law advantage to facilitate other paths to a restructuring, we turn to a closer examination of the two options mentioned above: a maturity extension and the imposition of a withholding tax.

\section{a. Maturity Extension}

A paper from 2011 (Edelen et al.), and two follow ups from 2019 (Cervantes et al. \& Cramer et al.), suggest that there might be a strategy to unilaterally extend maturities of debt with especially low coupon rates. ${ }^{30}$ Assuming this strategy is workable, the idea would be to ask the holders of local-law bonds with especially low coupons to voluntarily extend maturities. The addendum to that polite request would be that those who refused would have their maturities unilaterally extended by law.

The provision that the aforementioned papers hone in on is Article 3 of the Italian Public Debt Consolidated Act (the Debt Act"). Under Article 3:

[The Ministry] has the authority, within the annual limits established by the budgetary law, to issue framework decrees that allow the Treasury to ... proceed, in order to restructure

\footnotetext{
30 See Andrew Edelen et al, A Mature Approach: Using a Unilateral or Voluntary Extension of Maturities to Restructure Italian Debt (Jan. 10, 2013), at https://papers.ssrn.com/sol3/papers.cfm?abstract id=2077995 ; Emma Cervantes, Victoria Dodev, Shane Ellement \& Isabelle Sawhney, Reprofiling Today for a Sustainable Tomorrow: A Unilateral Italian Debt Restructuring (2019), at https://papers.ssrn.com/sol3/papers.cfm?abstract id=3371964 ; Matt Cramer, Brett Thorpe \& Charlie Saad, Buying Time: The Legal Case for Italy to Extend Maturities and its Effective Advantages and Disadvantages (2019), at https://papers.ssrn.com/sol3/papers.cfm?abstract id=3371944
} 
the national and external public debt, to the reimbursement before maturity of bonds, to the transformation of maturities. ${ }^{31}$

That language seems clear on its face. It says that the Ministry of Economy and Finance (the "Ministry") has the authority to issue decrees to allow the Treasury to either redeem bonds at par (maybe because interest rates have dropped considerably since issuance) or transform (extend) maturities (maybe because interest rates have increased considerably since issuance). In both cases, investors lose and would presumably impose a reputational cost on the issuer. But the options to either reduce or extend the duration of a loan are familiar contractual provisions in the debt world (particularly the former ${ }^{32}$ ).

One might question whether, if Italy does hit turbulent times, this power to extend maturities will be of much value. After all, countries in deep sovereign debt crises typically need to impose principal haircuts as well as maturity extensions. The objection is a fair one. But, given the large amount of the Italian debt that is held domestically and the negative impact to the economy that will likely be caused by imposing brutal principal haircuts to the holdings of domestic financial institutions, maturity extensions may be an attractive option for the government. This is especially so if a significant portion of the Italian debt stock was incurred when borrowing rates were especially low (as is the case) ${ }^{33}$

Under the structure of Article 3, the Treasury department receives the power to call bonds or extend maturities only if a framework decree authorizing such actions is issued by the Ministry. These decrees are not law; they are administrative actions implementing legal authority. They are also of limited duration. Each decree lasts for a year, no more. ${ }^{34}$ In prior years, they have been used to authorize the Treasury to do both debt exchanges

\footnotetext{
${ }^{31}$ (emphasis added). Decree of the President of the Republic of December 30, 2003, no. 398 (published in the Official Gazette of 9/3/2004, Supplemento ordinario no. 37).

32 For a discussion of redemption provisions in corporate bonds, see Marcel Kahan \& Mitu Gulati, Cash America and the Structure of Bondholder Remedies, 13 CAP. MKTS. L. J. 570 (2018).

${ }^{33}$ Italian bonds issued in 2019 carried an average interest rate of $1.07 \%$.

${ }^{34}$ D.P.R. 398/2003 (It.) at Art. 3.
} 
and redemptions..$^{35}$ It was also under Article 3's structure that a framework decree was issued by the Ministry to impose Euro CACs starting in 2013.

Let us say therefore that the Italian government decides to issue a framework decree in 2020 to authorize the Treasury, if need be, to extend the maturities of all Italian local-law bonds by five years. There are at least two possible barriers to the Treasury utilizing this authority. We take the potential barriers in turn.

\section{1. $\quad$ Article 8's You May Not "Pay Late" Instruction}

First, we consider Article 8 of the Debt Act. This is perhaps the most significant barrier to the use of Article 3. It requires that "payments of public debt [cannot be] reduced, paid late or subject to any special levy, not even in case of public necessity. ${ }^{36}$ The question then is whether extending maturities or reducing them (as Article 3 seems to allow the Treasury to do) violates the pay "on time" requirement. At first cut, it does not appear so, since that reading would reduce Article 3 to meaninglessness. ${ }^{37}$

That said, the argument could also be made that our reading of Article 3 reduces Article 8 to meaninglessness as well. And courts generally do not like to negate statutory provisions. The reality, therefore, is that if Italy decides to go down this path, a court will likely have to decide which of the clauses to favor, while putting a gloss on the other. And the hope for Italy would have to be that the court chooses to interpret Article 8 in a manner that weakens it, such as by reading it to require simply that whatever the maturity date is-whether shortened, lengthened, or kept the same-it has to be complied with.

The foregoing is not implausible in the context of the Euro CACs. The reason being that if Article 8 were to be interpreted to bar extensions of maturity, that would also negate crucial provisions of the CACs that, by Italian law, explicitly allow for the sovereign to extend maturities of the bonds with Euro CACs with a super majority approval of the

\footnotetext{
${ }^{35}$ See Dodev et al. supra note 30, at n.22.

${ }^{36}$ Edelen et al., supra note 30 .

37 ld.
} 
creditors. ${ }^{38}$ The question for the Italian government will be whether it wishes to go down this path of litigation. ${ }^{39}$

\section{The Euro CACs (Again)}

Earlier we discussed the question of whether the existence of the Euro CACs as a restructuring mechanism constrains the use of Article 3's power generally. Now, we address the question of whether the Treasury might use its Article 3 power in a specific bond that contains a Euro CAC as part of its contract terms. After all, if a crisis were to occur at any time over the next few years, there would be more Italian local-law debt with CACs than without. The Euro CACs have an explicit mechanism by which the maturities of the bonds can be extended, requiring a pre-specified vote of the creditors. Our view is that, for those bonds, the right of the sovereign to unilaterally extend the maturities is dubious. ${ }^{40}$ The reason being that these bonds already have a term explicitly governing how maturities may be extended. But for the remaining debt-which we estimate in the years 2020 to 2024 to range between 45 and $35 \%$ of the total debt stock (Figure 3)-there are no CACs.

For that latter subset, there is a strong argument that Italy can use the power that it already has by law to unilaterally extend maturities. We should caution though that such

\footnotetext{
${ }^{38}$ Dodev, et al., supra note 30. When Euro area countries inserted the Euro CACs into their bonds starting on Jan 1, 2013, they were all supposed to have modified their local legal structures to allow for the use of these CACs. So, presumably, there were memoranda that were written by Italian government lawyers at the time, certifying that Article 8 did not pose a barrier to maturity extensions via the CACs. Conversely, Article 8, if interpreted aggressively, could bar almost all of the restructuring techniques we discuss. For a discussion and analysis of these types of statutes in other countries and their dubious economic value, see Ugo Panizza et al., When Governments Promise to Prioritize Public Debt: Do the Markets Care? (2019 draft), at https://papers.ssrn.com/sol3/papers.cfm?abstract id=3371492

${ }^{39}$ Another objection that we have heard informally from some in the Italian government has to do with the Ministry's annual decrees issued between 2012 and 2019, which say that restructurings in those years will occur via "mutual consent". This guidance, we suspect, was a signal to the markets that restructurings would be done via a consultative process. There is no specification of what that consultatative process would be, nor have we been unable to uncover evidence of the intent behind the words "mutual consent". But we have reason to think that "mutual consent" does not mean that unanimous approval of creditors is required. There are two points worth considering here. Given that bonds issued after 2013 contain Euro CACs, "mutual consent" cannot possibly mean a requirement of unanimous creditor approval because that would contradict the explicit super majority requirements of the Euro CACs for maturity extensions. Further, the mutual consent requirement, whatever it means, comes out of an annual decree. It is up to the Ministry, every year, to decide whether it wishes to use that language in its decrees. If it happens to be a year where the Ministry wishes to give the Treasury to power to unilaterally extend maturities, it can delete the "mutual consent" language from that year's decree, as it has in many prior years.

${ }^{40}$ For discussions of the argument that the power of unilateral extension might apply to the bonds with CACs as well, see Dodev et al., supra note 30; Cramer et al., supra note 30.
} 
a power is unlikely to be unlimited. If the sovereign, for example, tried to extend the maturities of its one-year bonds by fifty years, there would likely be an immediate expropriation challenge.

Because the option of unilaterally extending maturities is likely to only work for local-law bonds that do not contain CACs and the relief that Italy would obtain would be limited compared to a more significant restructuring that reduces principal amounts as well as extending maturities, Italy may wish to pursue other options presented in this paper. However, if Italy wanted to make this tool a more feasible option for a future restructuring, it could reduce the litigation risk associated with this option by proactively clarifying the apparent discrepancy between Article 3 and Article 8. Indeed, deleting Article 8 might be even better.

\section{b. Withholding Tax}

Inherent to sovereignty is the power to tax. Bondholders who are owed moneys by a sovereign have, therefore, since time immemorial, worried about the sovereign deciding to impose a new tax on the payments it owes as a way to avoid payment. As a result, almost every international sovereign bond governed by the laws of New York or England contains what is called the tax gross up clause. This clause protects the bondholder against the sovereign deciding to levy an extra tax on the payments it owes on the bond as a way of doing a back door restructuring. ${ }^{41}$

Most local-law governed bonds, however, do not contrain such a protection. And that is the case for all of Italy's local-law bonds, except the small fraction of Luxembourg-listed ones mentioned earlier.

\footnotetext{
41 Buchheit explains how the clause works: "Any deduction as a result of the imposition of withholding taxes thus becomes the borrower's responsibility because the borrower's payment to the lender must [by virtue of the tax gross up clause] be topped up to compensate for the deduction." Lee C. Buchheit, How to NEGOTIATE EUROCURRENCY LOAN AGREEMENTS (1 ${ }^{\text {st }}$ ed. 1995).
} 
A simple strategy to deal with holdouts, therefore, is for the Minister of Finance to give a speech to local bankers in which she says that holdout bonds will be taxed so that the net (after tax) return will equal the payout on the new bonds. This was tried in Jamaica's restructuring of local-law bonds in 2010.42 The minister's threat was successful and he never in fact had to introduce the tax.

The fly in the ointment is if the country has bilateral investment treaties and double taxation treaties that bar such actions against the citizens of other countries. ${ }^{43}$ An Italian government considering such a strategy would need to consider the risk of litigation under these treaties. Indeed, it could reduce the risk of this litigation by being careful about the provisions it agrees to in future treaties. ${ }^{44}$

Taking steps to reduce litigation risk associated with an exercise of Italy's power under existing law to unilaterally extend maturities or impose a withholding tax on holdouts gives Italy additional options in a future restructuring. But neither of these options provides Italy with as much flexibility for significant debt relief as the option of retrofitting more effective CACs, described in the next section.

\section{Do a Lot}

Governments, as we noted at the start, are generally reluctant to do anything that might signal to the outside world that they are concered about the possibility of a financial crisis; even it everyone recognizes that it is a real possibility. So, "Do a Lot", is not a strategy we expect to be embraced.

Nevertheless, let us assume for purposes of this section that a sovereign such as Italy would want to minimize the future costs of potential holdouts in a possible restructuring. Operating under that assumption, we think that the strategy of enhancing the existing

\footnotetext{
42 We have found no mention of this technique in the sovereign debt literature. Unsurprisingly, sovereign debt restructuring guru, Lee Buchheit, advised Jamaica at the time.

43 We have not delved into the complexities of Italy's tax agreements with other countries.

44 The aforementioned Article 8 could pose a barrier here as well, since it bars any "special levy". As mentioned earlier, clarifying that Article 8 was not meant to pose such a barrier in advance of a crisis might be advisable.
} 
CACs in bonds that have them and retrofitting them in the debt that does not already have them is a good option for a number of reasons that we explain below.

As noted earlier, all Euro area sovereign bonds issued since 2013 with a maturity greater than one year already have CACs in them. But these CACs contain the requirement that a $66.67 \%$ vote of the holders, in principal amount, be obtained for each bond in order to use the aggregation feature to modify all of the bonds containing the CACs. And this creates a vulnerability to holdout creditors. Further, there is a whole set of debt instruments that are going to be even more vulnerable to holdouts, which are the bills with maturity under a year, the long-term bonds issued before 2013, government guaranteed instruments, non-bond debt (e.g., syndicated loans) and so on. The reason being that CACs were not made mandatory for these sovereign debt instruments. Euro area sovereigns could have inserted them voluntarily; but, as far as we know, none did. Realistically though, if the crisis is an especially serious one the government is going to need to restructure some of these instruments as well. ${ }^{45}$

Thus far, we've tackled the easy question of whether the sovereign might use one of its other powers - such as its taxing authority - to engineer a debt reduction without running afoul of the mandatory CACs. The answer was yes. The trickier, albeit closely related, question is whether the sovereign can enhance the existing CACs in its bonds by using its local-law authority.

By enhancing, we mean making changes to the existing model CACs provided by the European authorities to make the bonds even less vulnerable to hold out problems than they are now. In particular, two modifications that have already been the subject of debate among policy makers are:

\footnotetext{
${ }^{45}$ Conventional wisdom in sovereign debt restructurings is that short maturity instruments (under a year), trade credits, and guaranteed debt, generally get paid in full. But that assumption only holds where the the amount of debt in these instruments is small. In the recent Barbados restructuring of 2018-19, the amount of short-maturity debt was so large that it had to be restructured. And, since those instruments had no CACs, they had to be retrofit into them in the same manner that was done in Greece in March 2012. See Barbados: First Review, IMF Country Report 19/182 (June 2019), at imf.org.
} 
(a) introducing a mechanism by which the entire debt stock of a country can be modified at a single shot; for example, via a vote of $75 \%$ of all the holders across all the bonds, so long as some non-discrimination criterion is satisfied (the so-called single shot or single-limbed feature); and

(b) an addendum to the voting rules for modifications that disenfranchises the ECB from having its votes counted (assuming that the ECB continues to hold to the position that it is legally constrained from voting). ${ }^{46}$

Both changes to the existing Euro CAC structure correct for design flaws in the original 2013 version and enable the CACs to better achieve their goals of deterring holdouts while providing a clear and predictable mechanism by which creditors can participate in a burden sharing exercise. At the time the original Euro CACs were designed, it was thought that a bond-by-bond vote requirement of $66.67 \%$ would be enough to deter holdouts. And the implications of the ECB not being able to vote in a restructuring (or having to always vote no, regardless of the restructuring proposal) had not been fully considered. So, the question is whether an individual nation, such as Italy, concerned about the possibily of a crisis, can act on its own via its "local law" advantage to legislate improvements in its the CACs consistent with the original goals of those CACs.

There are two potential barriers here. First, for new bonds issued with the improved CACs, there is the question of whether deviating from the form mandated in 2013 violates European law. Second, for already-issued bonds where these provisions are retrofit via legislative action, there is the potential for creditor lawsuits claiming an interference with property rights. We take the possibilities in turn. Neither poses an significant barrier.

\footnotetext{
${ }^{46}$ For discussions of the design flaws in the current Euro CACs, see, e.g., Owen Sanderson, Next Generation Collective Action Clauses Roll Out, GLOBAL CAPITAL (April 2, 2015), at https://www.globalcapital.com/article/qv4k9g0h7jk3/nextgeneration-collective-action-clauses-roll-out ; Canepa, supra note 19; European Stability Mechanism, What Are SingleLimb Collective Action Clauses (CACs)? , at https://www.esm.europa.eu/content/what-are-single-limb-collectiveaction-clauses-cacs; Grégory Claeys \& Antoine Mathieu Collin, Does the Eurogroup's Reform of the ESM Toolkit Represent Real Progress?, Bruegel.org(Dec. 13, 2018), at http://bruegel.org/2018/12/does-the-eurogroups-reform-ofthe-esm-toolkit-represent-real-progress/; Sebastian Grund \& Mikael Stenstrom, A Sovereign Debt Restructuring Framework for the Euro Area, 42 FORDHAM J. INT'L L. 795, 837-39 (2019).
} 


\section{Legal Constraints Under the ESM Treaty}

A country including enhanced anti-holdout provisions in its new bonds potentially violates the instruction in the ESM treaty that CACs be introduced in a manner such that their "legal impact is identical". ${ }^{47}$ The argument against Italy being able to fix the design flaws in its CAC would be that all European countries are required to have the same flaws until the European authorities decide it is time to fix those flaws for everyone. ${ }^{48}$

There is a certain formalist appeal to the foregoing. "Identical legal impact" arguably means the same in every way. But, the very manner in which these Euro CACs were designed tells us that the creators could not have meant to use the term "identical legal impact" in such a broad fashion. The more likely meaning of "identical legal impact" is much narrower. That is, that every country would have an identical baseline of the same basic CAC framework that would signal to holders of sovereign bonds that a debt restructuring was possible. And that one way (not the only way) by which this restructuring could be implemented would be via the basic Euro CAC. And everyone had to have that identical baseline. There was no prohibition, however, on the sovereign enhancing the operation of the CACs by including additional provisions to its debt contracts. One way to see the foregoing is to compare the operation of CACs in the Italian foreign-law (New York law) versus local-law bonds.

The CACs in the Italian foreign-law bonds, such as the one issued in October 2019, are buttressed with all sorts of potent investor protections including acceleration clauses, cross default provisions, waivers of immunity, and consents to jurisdiction. What this means is that CACs in the foreign-law bonds, if the bondholder has the votes to block a restructuring attempt, can be turned into a potent litigation weapon. Assets can be seized,

\footnotetext{
47 Article 12(3) of the ESM Treaty says: "Collective action clauses shall be included, as of 1 January 2013 , in all new euro area government securities, with maturity above one year, in a way which ensures that their legal impact is identical,"

48 Some commentators do take this view. For example, Klaus-Albert Bauer writes: "A natural understanding of [ESM Article 12] this clause would seem to prohibit not only the issue of bonds with non-conforming collective action clauses but also the later unilateral amendment of Euro Area CACs to suit a particular issuer's needs in times of crisis." KlausAlbert Bauer, The Euro Area Collective Action Clause-Some Questions and Answers at 10, in COLLECTIVE ACTION Clauses AND the Restructuring of Sovereign DebT, supra note Error! Bookmark not defined..
} 
payments to other bondholders can be blocked and so. Conversely, in the local-law bonds that lack these protections, there is no weaponry for the holdout creditor other than the hope that the sovereign doesn't want to suffer the reputational cost of default. The point being that the issuer, by including a stand alone CAC in the local law bonds and not adding extra creditor protections, has an effective anti-holdout weapon, rather than the possible creditor weapon that the CAC tends to be in the foreign law bonds. Both the local and foreign-law bonds contain identical CACs, but they can potentially have radically different effects as a function of the other contractual bells and whistles that the issuer adds (or chooses not to add) to the baseline. And this was explicitly envisioned right from the start by the European authorities, who understood that sovereign bonds would be issued under both local and foreign law and that the sovereigns may want to include enhancements such as acceleration clauses or trustee structures. ${ }^{49}$

Plus, the actual CACs for foreign-law bonds were designed differently in one crucial fashion right from the start-the governing-law is a reserved matter that cannot easily be changed in the foreign-law bonds whereas it is not a reserved matter at all in the locallaw bonds. ${ }^{50}$ That is a significant difference, as Weidemaier (2019) points out. ${ }^{51}$ In other words, the CACs were designed such that they could not have identical impact (in its most literal sense) right from the start.

Given the foregoing, we think that the sensible interpretation of Article 12(3)'s dictates is that every Euro area nation needs to implement identical model CACs. But those serve as a baseline; ensuring that creditors all are forewarned that a restructuring of sovereign debt in the future is possible and that one method that might be used is the basic Euro CAC mechanism. Nothing, however, stops the sovereign from either adding in more investor protections (making the CAC a weaker tool from the sovereign's perspective) or adding improvements to the voting mechanism (making the CAC a stronger tool from the

49 See EFC Sub Committee on EU Sovereign Debt Markets, Model Collective Action Clauses: Explanatory Note, Section I (2012).

${ }^{50}$ See Weidemaier, supra note Error! Bookmark not defined.

51 ld. 
sovereigns's perspective) as long as the basic model CACs are kept in place. To reiterate, the Euro CACs serve as an identical baseline for all Euro area sovereigns.

From a policy perspective, it is easy to see why the foregoing makes sense. Euro area sovereigns vary vastly in terms of their economic strength and the types of markets they are able to tap. That means that they will likely need to offer different contractual rights to investors in order to borrow effectively; especially in a world where the European authorities have made it clear that they are not guaranteeing the payment of each individual sovereign's claims. To the extent a sovereign wants to prepare for a future crisis by experimenting with using enhanced restructuring tools that build on what the European authorities have already provided, and particularly if this is done in consulation with the European authorities, it is hard to see why those authorities would not wish that. The experimentation by different sovereigns with various enhancements can only serve to provide the authorities with helpful information.

Last but not least, there is the question of whether, even if there was a hypothetical violation of the Article 12(3) "identical legal impact" dictate, there would be any practical impact. With the caveat that the matter of international treaty enforcement is beyond our expertise, our understanding is that violations of treaty obligations generally only give the signatories to the treaty the right to bring legal actions. The presumption is that there are no private rights of action..$^{52}$ Here, if the European authorities are happy with the actions of the individual state, there is not going to be any complaining; just the clinking of champagne glasses.

\section{Interference With Property Rights}

If faced with a debt crisis situation and the need to protect against holdouts, Italy will likely wish to retroactively add the two enhancements mentioned above-the option of using

\footnotetext{
52 See Weidemaier, supra note Error! Bookmark not defined.. On private rights of actions under international treaties more generally, see Paul B. Stephan, Privatizing International Law, 97 VA. L. REV. 1573, 1607-11 (2011).
} 
single-shot CACs and the disenfranchisement of the ECB--to all of its already-issued and outstanding local-law governed debt.

The legal barrier to making such a retroactive change, we believe, is non trivial. The starting point in analyzing this question has to be the recognition that most modern legal systems disfavor retroactive changes to contract rights. ${ }^{53}$ Moreover, skepticism about the government's need to make such changes is likely to be especially heightened in contexts where the government is seeking to reduce its own debt obligations. ${ }^{54}$

To illustrate, let us say that the current Euro CACs allow the issuer the following options:

(a) If holders of $75 \%$ or more of an individual series of bonds (in principal amount) approve of a restructuring offer, that offer becomes binding on all holders.

(b) In a cross-series modification, if holders of $66.67 \%$ or more (in principal amount) approve of the restructuring offer, and $75 \%$ or more (in principal amount) of all the holders of the various series aggregated also approve of the offer, the offer is binding on all holders. ${ }^{55}$

To these existing options, let us now say that Italy wishes to add a third and different option, using its local law power. That option enhances the existing CACs by permitting, in the same fashion that is standard for bonds on the international (foreign law) market a single-shot restructuring option.

\footnotetext{
${ }^{53}$ For discussions, see Buchheit \& Gulati, supra note 5; Melissa A. Boudreau, Restructuring Sovereign Debt Under Local Law: Are Retrofit Collective Action Clauses Expropriatory, 2 HARV. Bus. L. ReV. 163 (2012).

54 This is one of the lessons of the famous gold clause cases of the 1930s where the US government used the local law advantage to abrogate the gold clauses in its bonds and in the bonds of private parties. See Boudreau, id. For additional detail, see Sebastian Edwards, AmERICAN Default: The Untold Story of FDR, THE SupREME COURT AND thE Battle Over Gold (2018); Georg Vanberg \& Mitu Gulati, Financial Crises and Constitutional Compromise, Chapter 7, in CONSTITUTIONS IN TIMES OF CRISES (Tom Ginsburg, Mark Rosen \& Georg Vanberg eds. 2019).

55 In the actual Euro CACs, there are additional options and different voting thresholds and quorum requirements for when the votes are taken at a physical meeting of the holders versus in writing.
} 
(c) In a cross-series modification, if the restructuring offer satisfies the condition that the terms are Uniformly Applicable to all holders, and $75 \%$ or more of the holders of all the series approve the offer, it will be binding on all holders. ${ }^{56}$

Let us also say that Italy wishes also to add in a provision to disenfranchise the ECB or any other supra national institutions that might be mandatorily required to vote one way or the other on a restructuring plan without consideration of the merits of the situation.

For bonds that were already issued, prior to the hypothetical Italian debt crisis, with either no CACs or the first-generation Euro CACs, these modifications will likely face legal challenge as a violation of property rights. Both the Italian constitution and European law provide protections for expropriations of property rights.

Article 42 of the Italian Constitution protects against interference with property rights unless the action is for reasons of "general interest" and the government makes "provisions for compensation". And Article 13 of the European Convention on Human Rights is similarly protective with protections for the peaceful enjoyment of property except under conditions of "public necessity". In such situations, the interference with property rights needs to be proportional to the public need. ${ }^{57}$

The two questions to ask, therefore, are (a) whether the inclusion by Italy of an additional option to the existing model Euro $\mathrm{CAC}$ and a provision disenfranchising the $\mathrm{ECB}$, in order to better tackle a financial crisis, would be ruled as the kind of action that was in the general public interest and proportional to what was needed, and (b) what compensation might be required, if there was a violation. ${ }^{58}$

\footnotetext{
56 This condition that the offer must be "Uniformly Applicable" is basically a non discrimination condition that was put in place in international bonds in 2014 when the single-shot CAC restructuring option was added to the standard terms. For more, see International Monetary Fund, Strengthening the Contractual Framework to Address Collective Action Problems in Sovereign Debt Restructuring, Paragraphs 34 \& 35 (Oct. 2014).

${ }^{57}$ See Weidemaier, supra note Error! Bookmark not defined. (discussing these two provisions); see also Boudreau, supra note 53 (analyzing a similar set of protections in the Greek context); Lee C. Buchheit \& Mitu Gulati, How to Restructure Greek Debt (2011) (similar), at https://www.ssrn.com/abstract=1603304.

58 The same analysis applies if we are considering the question of retrofitting these provisions into bonds without any sort of CACs.
} 


\section{Proportional to Need?}

The question of whether the retrofit inclusion of a single-shot CAC would survive the kind of proportionality analysis that was done by courts in the aftermath of the Greek 2012 restructuring has already been the subject of two excellent papers by Manuelidis (2019) and Weidemaier (2019). Both suggest that a retrofit of a single-shot CAC option would likely pass muster in the European courts. And although they do not analyze the question of adding in a provision that disenfranchises the ECB, we think that that would similarly be ruled to not be an undue interference with property rights.

The key case that helps predict how the retrofit would fare is the European Court of Human Rights' decision in Mamatas and Others v. Greece. Others such as Manuelidis (2019) have parsed the implications of the various portions of the court's discussion and we won't repeat that analysis here. ${ }^{59}$ However, it is helpful to boil down the core of the court's analysis in the Mamatas case and indeed a variety of other cases from the corporate context where corporations have put in place contractual modifications to help ameliorate a holdout problem. ${ }^{60}$

As we see it, the crucial question for the court will boil down to whether the sovereign has, in its use of the local-law advantage, acted opportunistically to take value away from the creditors and benefit itself. 61 Or, alternatively, whether it acted in the public interest in trying to fix flaws in the existing mechanism for restructurings so as to enable an orderly restructuring mechanism that benefits both the general public and the majority of creditors.

\footnotetext{
${ }^{59}$ Manuelidis also analyzes the important precedent of Germany retrofitting CACs into its local corporate instruments some years prior. See Manuelidis, supra note 2. Numerous others have also analyzed the implications of the litigation that followed the 2012 Greek restructuring. They do not, however, analyze the specific case of an Italian retrofit. See, e.g., Sebastian Grund, Restructuring Government Debt Under Local Law: The Greek Experience and Implications for Investor Protection Under European Law, 12 CAP. MKTS. L. J. 253 (2017); Astrid Inverson, The Future of Involuntary Sovereign Debt Restructurings, Mamatas and Others v. Greece and the Protection of Holdings of Sovereign Debt Under the ECHR, 14 CAP. MKTS. L. J. 34 (2019); Venetia Argyropoulou, International Arbitration and Greek Sovereign Debt, 19 Oregon Rev. INT'L L. 180 (2018); Andreas Witte, The Greek Bond Haircut: Public and Private International Law and European Law Limits to Unilateral Sovereign Debt Restructuring, 9 MANCHESTER J. INT'L ECON. L. 307 (2012). 60 E.g., Lee C. Buchheit \& Mitu Gulati, Exit Consents in Sovereign Bond Exchanges, 48 UCLA L. REV. 59 (2000).

61 See Weidemaier, supra note Error! Bookmark not defined..
} 
Assuming that the steps that Italy takes are in the vein of correcting flaws in the existing restructuring mechanism because of the possibility of an imminent crisis and, moreover, that they are similar to those that the European authorities have indicated are in the works for implementation across Europe anyway, it is hard to see how or why a court would rule the changes invalid. This is essentially what Greece did with its CAC retrofit in March 2012.

At the time of the Greek restructuring in 2012, European policy makers had already given the green light for a committee to design a CAC suitable for inclusion in all Euro area bonds. But that committee process took time, given that agreement from all the member states had to be obtained, and was not ready as of March 2012, by which time Greece was unable to wait any longer.

Therefore Greece's restructuring lawyers designed a CAC that basically was an advance version of what would subsequently be designed at the European level. ${ }^{62}$ Indeed, the experience with the use of the Greek designed clause has been useful in informing discussions of what kind of clause was appropriate for Euro-wide inclusion. More importantly for our purposes, it was important to the European Court of Human Rights-in the context of its approval of Greece's retrofit-that Greece had retrofit the kind of provision that was standard. ${ }^{63}$

\section{2. $\quad$ Damages}

Finally, there is the matter of damages. If it so happens that courts rule that Italy has violated property rights protections, the question to ask is what the monetary damages

\footnotetext{
62 For reflections on the design of the Greek restructuring from its primary architect, see Lee C. Buchheit, The Greek Debt Restructuring of 2012, GLOBAL RESTRUCTURING REV. (Mar. 20, 2017), at https://globalrestructuringreview.com/article/1138446/sovereign-debt-column-the-greek-debt-restructuring-of-2012

63 See Manuelidis, supra note 2. The fact that the voting thresholds that Greece in its retrofit CACs in 2012 were lower than those used in international bonds at the time did not trouble the courts (it had a simple $50 \%$ quorum and $66.67 \%$ aggregate vote requirement). Nor, for that matter, did the fact that Greece used the single-shot CAC that aggregated votes across all the series - a type of provision that is now standard, but was not at the time-trouble the court.
} 
would be. ${ }^{64}$ After all, if it turns out that the impact on the prices of the bonds from adding in features that improve their operation is an increase in the price of the bonds, then damages should be small (zero). And if damages are negligible, it should not matter if the courts find a technical legal violation. 65

Different legal systems analyze contract and expropriation damages differently. If viewed as a pure contract violation, the legal remedy in both civil and common law systems is what is called expectation damages; which is to give the aggrieved party the monetary amount that puts her back in the position she would have been had there not been the violation. ${ }^{66}$ And one way to measure that would be to look at the prices of Italian sovereign bonds before and after the retrofit.

Based on the existing empirical work on the pricing impact of including CACs in sovereign bonds, it is safe to predict that the impact of the retrofit will either be to increase the market price of the bonds (after all, they are less subject to the cost of holdouts now) or to have no price impact at all. ${ }^{67}$ That is, damages would be zero.

An alternative possibility would be for the court to ask what the value to the creditor would have been to be a hold out from the restructuring. We think it unlikely a court would go down this path, given how speculative the calculations would have to be. That is, unless the crisis has hit and the market begins pricing the holdout-friendly bonds at a premium to bonds that are easier to restructure. ${ }^{68}$ This may happen for two reasons. First, clauses that have to do with restructuring are likely to be more salient at time of crisis and hence

\footnotetext{
${ }^{64}$ In a situation where the retrofit is done to tackle a crisis, we are assuming a scenario where the litigation gets resolved some years after the restructuring has been conducted. That puts the remedy of specific performance out of the realm of consideration since a court is unlikely to be willing (or able) to unwind a sovereign debt restructuring.

65 This was the outcome in the Gold Clause case of the 1930s (Perry v. United States) that involved a constitutional challenge to the US government changing the terms of its own bonds retroactively. See Vanberg \& Gulati, supra note 54.

${ }^{66}$ For a discussion of comparative contract law remedies, see, e.g., Luca Ficetola, Comparing Remedies for Contract Violations in Italian and English Law (2012), at https://papers.ssrn.com/sol3/papers.cfm?abstract id=1990791

67 See Picarelli et al. supra note 17; Colla et al, supra note 17; Steffen et al., supra note 17.

68 The fact that there might be such a holdout premium for certain bonds does not mean that the judge will award damages as a function of the likelihood of a higher return for being a disruptive hold out. But it is a possibility. See, e.g., Paolo Colla et al., Pricing Bonds in a Crisis: Venezuelan Bonds in 2016, 11 CAP. MkTs. L. J. 540 (2016); Stephen J. Choi, Eric A. Posner \& Mitu Gulati, Pricing Terms in Sovereign Debt Contracts: A Greek Case Study, 6 CAP. MkTS. L. J. 163 (2011); Stephen J. Choi, Robert E. Scott \& Mitu Gulati, Hidden Holdouts: Contract Arbitrageurs and the Pricing of Collective Rights, Boston U. L. REV. (forthcoming 2020).
} 
may be taken more seriously and even misinterpreted during these periods. In tranquil times, however, markets may end up barely noting such an innovation. Second, if the sovereign takes action such as retrofitting CACs in the midst of a crisis, it is likely to be viewed as a signal that the sovereign's situation is worse than the market had anticipated. Furthermore, there may be a price differential simply because turbulent times are characterized by high price volatility. Assume that the price of a group of bonds happens to drop the day a retrofit is included in these bonds, a court may interpret this drop in price as linked to the inclusion of the retrofit even if this drop was purely driven by the high price volatility that characterizes turbulent periods.

Put simply, the greater the amount of daylight between when the retrofit is done and when the crisis hits, the smaller the likelihood of significant damages.

\section{Conclusion: To Buy Insurance or Not}

The choice our article poses is between doing something and doing nothing. This choice can be better understood if we frame the problem in the same way as we would frame the decision of whether we should buy insurance to protect ourselves from a particular event that may or may not occur in the future. In this case, the uncertain event is a debt restructuring event.

From the point of view of the borrowing country, the expected cost of a restructuring is $P \times C$; where $P$ is the probability that a debt restructuring will be needed and $C$ is the political and economic cost of the restructuring. $P$ and $C$, respectively, measure the probability and the cost of restructuring if the country does not do anything to protect itself.

If the country buys insurance (that is, if it does something along the lines described above), it will pay an insurance premium $s$, it will need to restructure with probability $\alpha P$, and, in case of restructuring, it will pay a cost $C^{\prime}$ (with $C^{\prime}<C$, for the reasons explained above). Hence, the expected costs if the country does something to protect itself will be: $s+\alpha P \times C^{\prime}$. 
The insurance premium $s$ captures the possible increase in the sovereign spread associated with doing something. This increase in spread could be due to either signaling or to moral hazard (or both). In the case of signaling, spreads may increase because, by doing something, the country reveals private information that signal that its debt situation is worse than what market participants thought. In the case of moral hazard, spreads may increase because the country now faces lower restructuring costs (remember $C^{\prime}<C$ ) and it is thus more likely to restructure its debt. Moral hazard would hence be reflected in a higher probability of a debt restructuring: $\alpha P>P$. Where $\alpha$ captures the increase in the probability of restructuring associated with doing something.

Doing something will be convenient if the expected cost of implementing a reform is lower than the expected cost of doing nothing. That is, if: $\left(s+\alpha P \times C^{\prime}\right)<(P \times C)$. This condition can be written as:

$$
s<P\left(C-\alpha C^{\prime}\right)
$$

We already discussed that $C^{\prime}$ is likely to be substantially smaller than $C$. Therefore, if the probability of a future restructuring in non-zero (i.e., $P>0$ ), and if moral hazard is not very important (i.e., if $\alpha$ is not much larger than one) $P\left(C-\alpha C^{\prime}\right)$, will be positive. But what do we know about $s$ ?

The existing evidence suggests that $s$ is likely to be very small, or even negative. For instance, multiple papers find that that the introduction of CAC in European bonds was associated with a reduction (and not an increase) in yields: pointing to the idea that $s$ could be negative (or, for sure, not positive and large). Note that this is view also seems to be shared by the Italian authorities. Italy recently issued a dollar bond which included all sorts of creditor protections, but according to the Director General for Public Debt of the Italian Treasury if the bond had been issued under local terms and priced in euros the yield would have been broadly in line with the current yield on Italy's benchmark 10-year 
BTP bonds. ${ }^{69}$ In fact, the spread over US Treasuries of the Italian dollar bonds (150 basis points) was basically identical to the spread of Italian BTPs over German Bunds.

Taken together the evidence on bonds with CACs indicates that the market does not penalize bonds that are easier to restructure and anecdotal evidence on the recent Italian bond issuance suggests that the market does not seem to reward bonds that have clauses that make them especially creditor friendly. This all suggest that $s$ is likely to be very close to zero. But if $s$ is close to zero, then the moral hazard problem (which contributes to $s$ ) is unlikely to be very important making $\alpha$ close to one. Hence, as long as the probability of restructuring is nonzero the condition that $s<P\left(C-\alpha C^{\prime}\right)$ is likely to hold and the option of doing something now dominates that of doing nothing.

In theory, that is.

69 See Giuseppe Fonte, Italy Plans to Issue More Foreign Currency Bonds Next Year, REUTERS, Oct. 10 (2019), at https://www.cnbc.com/2019/10/10/reuters-america-update-1-italy-plans-to-issue-more-foreign-currency-bonds-nextyear.html 